\title{
Comparison of hydroxylated print additives on antibody microarray performance
}

\author{
Peng Wu and David W. Grainger \\ Department of Chemistry, Colorado State University, Fort Collins, CO 80523-1872 USA
}

\begin{abstract}
Various hydroxylated additives were added to antibody print buffers at different concentrations to stabilize printed antibodies during normal array spot desiccation on commercial polymer-coated microarray slides. Polyvinyl alcohol addition to print buffers produced the most regular spot morphologies, homogenous intra-spot antibody distribution, uniform fluorescence intensity, and improved analyte capture activity, maintained up to 1 month at $4{ }^{\circ} \mathrm{C}$ for capturing model analytes, anti-human IL-1 $1 \beta$, IL-4 and TNF $\alpha$, on these microarraying slides.
\end{abstract}

\section{Keywords}

microarray; antibody; surface chemistry; immobilization; assay; diagnostics; shelf life

\section{Introduction}

Antibody microarrays exploit the surface immobilization of different antibodies into isolated micro-domains as capture reagents for immunoassay 1,2 . These formats remain of considerable interest to in the fields of proteomics, diagnostics and therapeutics ${ }^{3}$. Many technological issues remain for antibody microarrays to become a quantifiable, reliable technology validated for both diagnostic assay and proteomics use. These include challenges with absolute quantitation, analyte detection limits, assay reliability and reproducibility, antibody batch-batch variance, print conditions, and assay storage variables 4,5 . Antibody microarrays have the potential to become a new, attractive characterization method for molecular mixtures at the protein level that DNA microarrays already make possible at the RNA and DNA level ${ }^{6}$. However, as the diagnostic, bioreactor and biosensor fields have shown for decades 7,8 surface-immobilized globular proteins (e.g., antibodies) have much more complex requirements for stabilizing intrinsically less robust native structures to provide their exquisite assay capture selectivity compared to immobilized nucleic acids (e.g., RNAs and DNAs). Hence, protein-surface interactions remain much more of a critical issue for antibody array performance. Print buffers, print conditions, protocols for antibody surface immobilization, storage routines and assay formats still require optimization and improvements to facilitate acceptance of this technology as a standard quantitative assay 3 .

Many possible stresses influence immobilized antibody activity after microarray printing onto solid supports. Evaporation of printing solution (typically droplets originally containing antibody in aqueous media at sub-milligram per milliliter concentrations, dispensed as nanoliter volumes onto surfaces) during and after the printing process causes rapid increases in solute concentrations, ionic strengths, hydration changes of antibodies, $\mathrm{pH}$ shifts, and

*To whom correspondence should be addressed at current address: Department of Pharmaceutics and Pharmaceutical Chemistry, University of Utah, Salt Lake City, UT 84112-5820 USA, tel: +1 801581 4532, email: david.grainger@pharm.utah.edu. 
modification of surface energetics as the three-phase (e.g., solid-liquid-air) line moves across the drying proteins spots upon water evaporation. Since the surface energy of pure water is $\sim 72 \mathrm{mN} / \mathrm{m}$ at room temperature and only slightly less for salt-containing buffers ${ }^{9}$, the immobilized protein species is subject to enormous local forces that can readily dismantle native globular protein structure, reducing antibody bioactivity. Even hydrogel "protein friendly" surfaces do not appear to be a complete solution for providing the necessary capability to preserve bioactivity and structure of desiccated immobilized proteins ${ }^{7}$.

By comparison, bulk proteins are typically carefully lyophilized in attempts to maintain stability over storage periods of many months. However, many analogous stability and reliability problems remain unsolved for these materials as pharmaceuticals ${ }^{10}$. Problems are compounded when globular proteins are printed as thin films on surfaces and then subjected to the same destabilizing drying and interfacial conditions. This scenario really constitutes a 'return to the past' for many protein-surface biophysical chemistry issues that have been wellstudied (but nonetheless remain unsolved) in the areas of soluble protein surface adsorption, protein-surface stabilization, and protein denaturation on surfaces $11-15$. Despite problems, the advantages of surface printing of protein microarray formats include the capability to print many more protein molecules onto a surface than can possibly bind by solution adsorption into that footprint, and the use of surface sorption and rapid evaporation of printed droplet to "force" protein-surface immobilization during spot drying. Evidence is lacking to confirm roles of microarray surface chemistry and its functional reactive group densities in this reaction in the few seconds between liquid spot deposition and drying. Certainly, the non-equilibrium drying dynamics occurring in protein microarray fabrication from rapid evaporation of nano-liter drops printing solution dispensed on microarray substrates 5,16 present unique protein-surface conditions that are not duplicated or studied in previous protein interfacial studies. Such microarray immobilization differs from standard enzyme-linked immunosorbent assay (ELISA) in which capture antibodies are immobilized onto solid substrates under bulk solutionphase, extended-time surface saturating conditions. These solution-phase ELISA conditions produce antibody immobilization densities and protein states distinct from printed microarray formats, while lacking certain microarray advantages including reduced antibody consumption, dense assay features and highly parallel assay formats. Recently developed highthroughput microarray-based ELISA is compatible with automated robotic microarray printing systems, and faces the same issues of non-equilibrium drying during immobilization 17 .

Recently, several studies using contact microarray printing for optimizing protein and antibody microarray immobilization, protein assay and storage conditions have been published ${ }^{18-20}$. In one case, five different antibodies were immobilized onto eleven different array surfaces. Direct label assay using Cy 3 or Cy5 fluorescent dye-labeled antigen was used to show that some antibodies are intrinsically more suited for use on antibody arrays than others.

Furthermore, this work suggested that antibodies for array use should be screened for their suitability in this specific capture application. Importantly, no significant performance or stability differences were shown between immobilized antibody microarrays on non-hydrogelcoated surfaces stored dry at $4{ }^{\circ} \mathrm{C}$ compared to those stored wet in blocking solution at $4{ }^{\circ} \mathrm{C}$. However, hydrogel-coated slides exhibited higher signal intensities in dry conditions, due to loss of coated antibodies into the blocking storage solution under wet storage ${ }^{18}$. Another study systematically compared protein microarrays using direct label versus sandwich immunoassay for parallel detection of five cytokines and growth factors on four different array printing slides. Sandwich format outperformed the corresponding direct label assays in terms of backgroundsubtracted fluorescent intensity, although the extent varied for different slides examined and antibodies capturing cytokines and growth factors ${ }^{4}$. Antibody sourcing and batch-batch variations, intrinsically different affinities against different antigens, and differential effects of surface immobilization on antibody surface capture affinities and stabilities in arrays all present a complex scenario for understanding signal generation in this format. 
Hydroxylated additives including trehalose, sucrose, glucose, polyethylene glycol (PEG), and glycerol have all been commonly used as bulk protein cryo- and lyo-protectants, preserving bioactivity during bulk lyophilization processes 21 . Different hypotheses have been proposed to explain the mechanisms of protection by such excipients during the lyophilization cycle, including the (a) vitrification hypothesis 22,23 proposing that amorphous protein stabilization can only be achieved if another amorphous compound provides immobilization and spatial separation in a glassy, solid matrix during dehydration; (b) "water replacement hypothesis" $24,25,26$ wherein hydroxylated additives stabilize proteins by hydrogen bonding and other weak forces of attraction to protein polar and charged groups of proteins, replacing the water loss, thus preventing drying-induced protein denaturation; and (c) "preferential hydration" or "preferential binding" concept wherein stabilizing additives are preferentially excluded from the protein surface, leading to an apparent increased protein hydration and improved stability 27,28 . Different mechanisms may account for specific protein stabilization systems depending on the type of protected proteins, stabilizing additives, and lyophilization conditions. Moreover, a consensus has recently emerged that these mechanisms are not necessarily mutually exclusive ${ }^{29-31}$.

Little is yet published that thoroughly investigates effects of additives in applications to antibody microarray performance. One study using direct label assay with Cy3- or Cy5- labeled antigen investigated various factors in the production of antibody microarrays on home-made and commercially available slides ${ }^{19}$. Addition of trehalose into the PBS buffer increased antibody capture activity coupled to several home-made silane glass slides with cross-linkers. Surprisingly, no substantial differences were observed using several different print buffers (carbonate buffer, $\mathrm{pH}$ 8.5; PBS buffer, $\mathrm{pH}$ 7.4; acetate buffer, $\mathrm{pH} 5.5$; and citrate buffer, $\mathrm{pH}$ $4.5)^{19}$. In another study seeking to improve protein stability in microarrays on commercial aldehyde-coated glass slides ${ }^{20}$, additives including trehalose, sucrose, glycerol and PEG (mol. wt. 200) were added to PBS print buffer. PEG (mol. wt. 200, 30\% w/v) greatly improved printed streptavidin stability and activity, whereas trehalose, sucrose and glycerol showed no improvement or even decreased activity compared to PBS buffer without any additive. Improved capture performance using PEG (mol. wt. 200) was explained by reduced water evaporation rates of printed microarray spots and preferential hydration and hydrophobic interactions between PEG and streptavidin in spots on surfaces ${ }^{20}$. In several other microarray contact printing studies, relatively high percent $(20 \sim 50 \%)$ glycerol has been added to protein microarray print buffers to inhibit nanoliter droplet evaporation 32,33 . However, printing with such high concentrations of additives produces print problems including pin clogging during protein spotting, high spot background and spot smearing, especially in high viscosity solutions (e.g., with 20 50\% glycerol additives). Additive adsorption on the interior walls of contact print pins increases the well-known "carry-over effect" (e.g., residual print solution carried into the next print sample reservoir, even if these pins are repeatedly rinsed and dried between prints ${ }^{34}$ ).

Mechanisms of protein stabilization by hydroxylated additives in microarray printing/drying cannot be simply extrapolated from bulk protein stabilizing hypotheses invoked for bulk protein lyophilization or spray drying process due to numerous, complex interactions between proteins and array surfaces. Microarray printing process variables, including substrate surface characteristics (e.g., surface hydrophilicity, surface chemistry, polymer layer thickness, density), different print conditions (e.g., antibody sources, print buffers, print chamber humidity, non-contact versus contact printing, contact pressure between spotting pins and slide surfaces) will produce different spot morphologies, homogeneities and immobilized protein densities, and, therefore, different distributions of protein and stabilizing additives in spots on surfaces, leading to different local stabilizing environments. 
In this study, several soluble hydroxylated additives were analyzed in contact-printed protein microarrays. Three common cytokines were selected as model analytes and assayed using a sandwich assay format on two commercially available amine-reactive microarraying slides. Over the past decade, cytokine detection has been an increasing bioassay focus. Regulation of cytokine production is involved in the pathogenesis of various diseases, and in trauma and healing. Rapid, reliable, multi-plexed determination of cytokine levels is therefore of increasing diagnostic importance 35,36 . Print-immobilized microarrays were stored dry at $4^{\circ}$ $\mathrm{C}$ to investigate antibody activity after 1 month. Effects of covalent binding and physisorption upon spot drying between printed antibodies and reactive groups on microarraying slide surfaces were also studied.

\section{Experimental Methods}

Commercially sourced, printed capture antibodies and secondary biotinylated sandwich antibodies used in all experiments are listed in Table 1. Antibodies, recombinant human IL-1 $\beta$ (mol. wt. $17 \mathrm{kDa}$ ), TNF $\alpha$ (mol. wt. $17.4 \mathrm{kDa}$ ) and IL-4 ((mol. wt. $14 \mathrm{kDa})$ cytokine analytes (Pierce, Rockford, IL), streptavidin-Alexa Fluor® 647 conjugate, Alexa Fluor ${ }^{\circledR} 555$ goat anti-mouse IgG and biotinylated goat anti-mouse IgG (Molecular Probes, Eugene, OR) were aliquoted immediately after receipt according to manufacture's recommendations and stored frozen at $-70^{\circ} \mathrm{C}$.

\section{Antibody Array Printing}

Antibodies were printed onto two commercial arraying slide surfaces, Optarray ${ }^{\mathrm{TM}}$ (Accelr8 Technologies, Denver, CO) and Codelink ${ }^{\mathrm{TM}}$ (Amersham, Piscataway, NJ). Both slides are aminereactive, three-dimensional hydrogel-type coated glass slides (not monolayer silane chemistries): OptArray ${ }^{\mathrm{TM}}$ is a 20 -nm thick crosslinked polymer based on derivatized polyethylene glycol, whereas Codelink ${ }^{\mathrm{TM}}$ is a polymer coating based on a polyacrylamide copolymer according to their respective product literature 16 . Additives including polyethylene glycol (PEG, mol.wt. of 150, 750, 2000 and 6000, J.T.Baker Chemical Co., Phillipsburg, NJ), polyvinyl alcohol (PVA, mol.wt. 9000-10000, Aldrich, Milwaukee, WI) trehalose (Sigma, St Louis, MO), D-glucose and sucrose (Fisher Scientific, Fair Lawn, NJ) are added in different concentrations to base print buffer containing $0.25 \mathrm{M} \mathrm{Na}_{3} \mathrm{PO}_{4}, 0.005 \%$ Tween 20 , and $0.05 \mathrm{M}$ $\mathrm{NaCl}(\mathrm{pH}=7.5)$. Capture antibody concentration is $100 \sim 200 \mu \mathrm{g} / \mathrm{ml}$. A SpotBot ${ }^{\circ}$ Personal Microarrayer (TeleChem International, Inc., Sunnyvale, CA) and quill pins SMP6 (spot diameter $200 \mu \mathrm{m}$, delivery volume $1.8 \mathrm{nl}$, TeleChem International, Inc., Sunnyvale, CA) are used in this experiment to contact-print antibodies onto both commercial slide formats. Relative humidity of $65 \sim 70 \%$ is maintained throughout the printing process. Printed biotinylated goat anti mouse IgG was chosen as a printed capture positive control because of its direct interactions with the streptavidin-Alexa Fluor ${ }^{\circledR} 647$ sandwich fluorescent label without significant concern about lost printed antibody bioactivity influencing fluorescence signal in the $\mathrm{Cy} 5$ channel (e.g., capture is only biotin-streptavidin, not antibody binding site mediated). Buffer lacking any capture antibody served as a negative printed control. Stable surface immobilization was attempted by storing printed microarray slides under nitrogen overnight at $4^{\circ} \mathrm{C}$. Thereafter, residual amine-reactive groups on printed microarray slides were blocked using ethanolamine $(1: 500 \mathrm{v} / \mathrm{v})$ in $50 \mathrm{mM}$ sodium borate buffer $(\mathrm{pH}=9.1)$. Slides were then rinsed with PBS and Millipore water, and finally dried under nitrogen. These microarray slides were then applied to anti-human cytokine sandwich immunoassay. For longer period storage periods, slides were stored sealed under nitrogen at $4^{\circ} \mathrm{C}$ after blocking, rinse and drying with nitrogen.

To investigate the importance of covalent binding in printed antibody microarray immobilization, both amine-reactive microarraying polymer surfaces (OptArray ${ }^{\mathrm{TM}}$ and Codelink $^{\mathrm{TM}}$ slides) were first blocked using ethanolamine $(1: 500 \mathrm{v} / \mathrm{v})$ in $50 \mathrm{mM}$ sodium borate 
buffer $(\mathrm{pH}=9.1)$ before identical microarray printing. These pre-blocked slides were then compared with slides printed without pre-blocking using anti-human cytokine sandwich assays.

\section{Microscope imaging of printed microarray spot morphology}

A Nikon Eclipse TE 2000-U microscope (equipped with Plan Fluor ELWD 40 X Nikon objective) is used to observe printed microarray spots on commercial microarraying slides. Differential interference contrast (DIC) mode is used to observe printed, dried microarray spots. Images were taken on printed microarray slides stored under nitrogen overnight at $4^{\circ} \mathrm{C}$ before blocking and rinsing.

\section{Anti-human cytokine sandwich immunoassay}

Human IL-1 $\beta$, a clinically relevant inflammatory cytokine, was assayed using a sandwich immunoassay format with array-printed anti-human IL-1 $\beta$ antibodies on solid supports 4,37 (Figure 1). Recombinant human IL-1 $\beta$ model analyte was diluted in incubation buffer (PBS buffer, $\mathrm{pH}=7.5+0.05 \%(\mathrm{v} / \mathrm{v})$ Tween $20+0.1 \%(\mathrm{w} / \mathrm{v}) \mathrm{BSA}$ ) at $20 \mathrm{pg} / \mathrm{ml}$ to $20 \mathrm{ng} / \mathrm{ml}$ and incubated on-array for $1.5 \sim 2$ hours using CoverWell ${ }^{\mathrm{TM}}$ perfusion chambers (Grace Bio-Labs, Inc., Bend, OR) under $100 \%$ humidity. Slides were then rinsed with PBST (PBS buffer $+0.01 \%$ $(\mathrm{v} / \mathrm{v})$ Tween $20, \mathrm{pH}=7.5)$ and water, then dried with nitrogen. Biotinylated secondary antihuman IL-1 $\beta$ (biotin) was diluted to $\sim 6.6 \mu \mathrm{g} / \mathrm{ml}$ in incubation buffer solution from $1 \mathrm{mg} / \mathrm{ml}$ frozen stock and incubated on-array for 1 hour. After repeated rinsing with PBST/water and drying with nitrogen, arrays were finally incubated for 30 minutes with streptavidin-Alexa Fluor ${ }^{\circledR} 647$ conjugate $(5 \mu \mathrm{g} / \mathrm{ml})$ and Alexa Fluor ${ }^{\circledR} 555$-goat anti-mouse $\operatorname{IgG}(5 \mu \mathrm{g} / \mathrm{ml})$ together in incubation buffer. Alexa Fluor ${ }^{\circledR} 555$-conjugated goat anti-mouse $\operatorname{IgG}$ was used to verify surface loading of printed capture antibody, whereas Alexa Fluor® 647-conjugated streptavidin was used to verify bioactivity of printed capture antibody for sandwich assay capture of cytokine analyte. Human TNF $\alpha$ and IL-4 analytes were assayed in the same format with corresponding array-printed capture antibodies and biotinylated secondary antibodies. To investigate assay specificity, anti-human TNF $\alpha$ was used as a negative printed control for human IL- $1 \beta$ assay, whereas anti-human IL- $1 \beta$ was used as a negative control for human $\mathrm{TNF} \alpha$ and human IL-4 assays.

\section{Microarray fluorescence detection and image processing}

All substrates were imaged using a Perkin Elmer ScanArray Express ${ }^{\mathrm{TM}}$ Microarray Scanner with two selectable lasers with wavelengths $543 \mathrm{~nm}$ (Cy3 channel) and $633 \mathrm{~nm}$ (Cy5 channel). Resolution was set to 5 microns, and power and gain settings were fixed for all scanning measurements. All microarray scanned fluorescence images were processed with ScanArray Express $^{\mathrm{TM}}$ software. Intensities (mean intensity of the spot minus off-spot background) from spotted replicates $(n=5)$ were averaged and standard deviations calculated. Altogether, data from more than 100 microarrays and 30 individual experiments were considered. Although fluorescence intensity varies between individual experiments, and different batches of printed slides, the data trends are all very similar, with representative data shown.

\section{Results and Discussion}

\section{Antibody microarray spot morphology}

During microarray printing, nanoliter droplets were delivered from pins onto microarraying slides. Even in the 65\% 70\% relative humidity chamber, evaporation of this droplet occurs within a few seconds, rapidly depositing an aggregated protein film on the substrate surface. Microscope images were compared in parallel with fluorescence-scanned images of antibody microarray spots (Figure 2). For each sample, the left image in Fig. 2 is the CCD image from 
DIC microscopy mode before blocking and rinse, and the right image is the fluorescence scan (Cy3 channel after capture assay). This Cy3 channel signal shows fluorescence from the Alexa Fluor ${ }^{\circledR} 555$ goat anti-mouse $\mathrm{IgG}$, which directly binds to all printed murine capture antibodies, allowing direct examination of capture antibody printing loads. Phase contrast microscopy was also used to capture high contrast spot images, producing similar images on these microarray spots as DIC but with slightly higher contrast in DIC modes (hence, these images are not shown in Figure 2). Direct comparison of these images side by side provides important new information about distributions of printed antibodies, hydroxylated additives, and salt contents in the print buffer remaining after rapid evaporation. These dry spots are about $100-200$ microns in diameter, while the resolution of the fluorescence scan is 5 microns. Fluorescence signal in Figure 2 represents presence of capture antibodies on the surface. Although little quantitative information about thickness, or surface density of capture antibodies can be derived from these fluorescence images, rough distributions of capture antibodies within spots are clearly observable. As assessed from fluorescence images in Fig. 2, adding PVA (mol.wt. $9000,0.5 \%$ and $0.05 \% \mathrm{w} / \mathrm{v}$ ) to print buffer produces the most homogenous capture antibody distribution (see calculated data for intra-spot fluorescence intensity variations in Figure 2), with regular round spot morphologies and smallest variance from spot to spot. Figure 2 DIC images show that PVA facilitates evenly spread films on the surface with homogenous capture antibody mass within this film. By contrast, adding PEG (mol. wt. 150 and 2000, 5\% w/v and $0.5 \% \mathrm{w} / \mathrm{v}$ ) to print buffer produced double-ring (donut) fluorescence images on Codelink ${ }^{\mathrm{TM}}$ slides (bright fluorescence signal at both spot center and outer edge, but very low signals in other areas), and only bright fluorescence signals at the very spot center on OptArray ${ }^{\mathrm{TM}}$ slides. This fluorescence distribution pattern is also related to the drying patterns observed in corresponding DIC microscope images. At the outer edges of spots on OptArray ${ }^{\mathrm{TM}}$ slides, most visible are salt particles from the print buffer: no signal is observed at these outer edges in the corresponding fluorescence images. On Codelink ${ }^{\mathrm{TM}}$ slides, fluorescence signals concentrated at outer edges of microarray spots are attributed to antibodies at the outer edge of the spot usually caused by common "coffee-spot" drying effects $38_{\text {- rapid drying causing spotting }}$ solution (including antibodies) to wick and dry to the outer edge of the spot during the printing process. This typically occurs when the humidity in the microarray printing chamber is relatively low 39 . However, here, microarray printing is controlled to $65 \sim 70 \%$ humidity, so "donut shapes" are not observed when printing with print buffer lacking hydroxylation additives. Fluorescence signals at the outer edges of PEG/antibody printed spots exhibited only on Codelink ${ }^{\mathrm{TM}}$ but not on OptArray ${ }^{\mathrm{TM}}$ slides are partially due to PEG additives, and partially due to higher hydrophilicity of Codelink ${ }^{\mathrm{TM}}$ polymer surface ${ }^{40}$, causing the spotting solution to spread to outer spot edges faster, producing double-ring patterned fluorescence images.

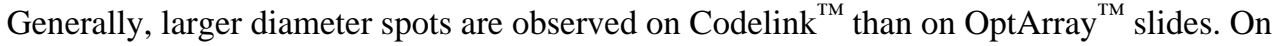
both slides, PEG addition confines antibody molecules near the spot center, producing high spot-spot and array-array spot morphology and fluorescence intensity variations (Figure 2). Adding trehalose and glycerol to print buffer seems to induce formation of glassy amorphous spots (adding glucose or sucrose produced similar images as adding trehalose, images not shown). However, from corresponding fluorescence images (Figure 2) antibody distributions in these spots are not as homogeneous as in spots printed with PVA additives.

\section{Comparison of hydroxylated additives on capture activity}

Quantified fluorescence intensity from streptavidin-Alexa Fluor® 647 (Cy5 channel) indicated a relative analyte capture bioactivity in sandwich assays of capture antibodies printed with different hydroxylated additives. As shown in Figure 3, adding PVA (0.5\% and 5\%) to print buffer produced the highest capture antibody bioactivity observed (anti-human IL-1 $\beta$, TNF $\alpha$ and IL-4) on both OptArray ${ }^{\mathrm{TM}}$ and Codelink ${ }^{\mathrm{TM}}$ slides. Adding glycerol (2\% v/v) also improved antibody capture activity, especially on OptArray ${ }^{\mathrm{TM}}$ slides. Further experiments (see below) showed that adding glycerol $(2 \% \mathrm{v} / \mathrm{v})$ to print buffer produces false positive signals on 
OptArray ${ }^{\mathrm{TM}}$ slides (Figure 4). Surprisingly, trehalose, with its reputation as an exceptional protein stabilizer $41-43$, did not exhibit much improved antibody capture activity compared to antibodies printed without any additive. Similar performance was observed for glucose and sucrose. These observations are consistent with the study by Lee et al. ${ }^{20}$ but differ with results from Kusnezow et al. ${ }^{19}$. However, even in the latter study, increases in bioactivity (from $30 \%$ to $~ 150 \%$ increases) using trehalose are different on different microarray substrates. The printing surface plays an important role in microarray spotting and immobilization, producing different spot morphologies, sizes, immobilized densities and stabilizing effects from hydroxylated additives.

Amounts of antibodies or proteins in printed nanoliter droplets for microarray spots $\left(\sim 10^{-15}\right.$ mole) are much greater than that required for an immobilized antibody/protein monolayer $\left(\sim 10^{-16}\right.$ mole per spot assuming IgG has a footprint of $\left.\sim 100 \mathrm{~nm}^{2} 44\right)$. After complete droplet evaporation in a few seconds following spotting, stacked, aggregated multi-layers of antibody/ protein form into each microarray spot. The drying is a non-equilibrium event: antibody concentration rapidly increases from $\mu \mathrm{g} / \mathrm{ml} \sim \mathrm{mg} / \mathrm{ml}$ to saturation in seconds, producing irreversible antibody aggregation. There is no control over either deposited thickness or antibody immobilization orientation. Dried antibodies adsorb onto surfaces in any orientation through multi-point contacts by mixtures of covalent bonds, hydrogen bonds, electrostatic or other physical interactions. Rapid spot drying onto the surface promotes irreversible surface adhesion of printed proteins, ${ }^{45}$, resulting from protein denaturation, aggregation and conformational changes in drying proteins on all surfaces. During blocking steps, loosely attached proteins are washed away from the surface, with only strongly adsorbed antibody multilayers remaining both in the presence and absence of covalently reactive surface groups 45 . Final antibody print densities, amounts, and fractional bioactivities post-print are largely unreported.

Adding PVA produced the most homogenous antibody printed distribution, and largest diameter dried spots on both OptArray ${ }^{\mathrm{TM}}$ and Codelink ${ }^{\mathrm{TM}}$ slides. Antibody/PVA mixtures are evenly distributed across microarray spots, meaning less antibody aggregation, and improved availability of antibody binding domains for analyte capture in sandwich assays. These effects are attributed to several properties, including PVA surfactancy that promotes droplet-surface spreading, uniform wetting and contribution to protein drying 46-48. Several studies have shown that freeze-drying processes produce more extensive protein structural changes than that of dehydration at ambient temperature ${ }^{49-52}$. The latter does not necessarily result in large changes in protein structure, such as unfolding, although some secondary structural or conformational distortions can occur $49,53,54$. Beyond just the removal of water directly associated with the protein, freeze-drying provides extra mechanisms for denaturation or large distortions of protein structure. These mechanisms including "cold denaturation" processes (the temperature of a protein sample during freeze-drying might approach the cold denaturation temperature, see review ${ }^{49}$ ), and $\mathrm{pH}$ or ionic strength changes as the solution components are concentrated.

It seems reasonable to suggest, therefore, that protein/antibody unfolding and large structural or conformational changes, if any, in microarray printing process are not due simply to dehydration, but to other extra stresses/mechanisms such as sudden ionic strength and pH shifts, and interplay with surface energetics (vida infra). Hence, thermodynamic (water replacement) or dynamic protecting mechanisms (e.g., vitrification hypothesis) 55 of traditional freezedrying lyoprotectants such as trehalose, sucrose and other sugar molecules do not likely apply in microarray printing processes at ambient temperature. In contrast, if proteins/antibodies do not unfold or exhibit structural changes from the microarray printing process, the observed low bioactivities of capture antibodies are probably contributed by protein aggregation and misoriented binding domains that are unable to bind target analytes in solutions. PVA apparently 
can improve antibody capture activity through improved distribution of antibodies/PVA mixtures in microarray spots. Additionally, unlike sugar additives, PVA decreases aqueous surface tension and is well-known as both a colloid protective agent 46,48 and stabilizing agent in spray-dried protein particles 47 . It is possible that the PVA, as a polymeric surfactant, preferentially adsorbs to droplet surfaces, displacing protein from the surface ${ }^{47}$, and reducing local stress on proteins from surface energetics during solution evaporation. In summary, no additives are as effective as PVA in promoting preferential antibody distribution and immobilization on these surfaces. Beyond PVA and glycerol, none significantly improve antibody binding activity in analyte capture assays.

\section{Covalent antibody immobilization in microarray printing}

The role of covalent binding in antibody spotting and immobilization in microarray contact printing was assessed by comparing capture antibody activities printed on both normally amine-reactive and non-reactive slides (slides pre-blocked with ethanolamine). Capture antibodies were printed using print buffer lacking any additive, or with either PVA or glycerol. As shown in Figure 3, these two additives provided the best performance among all hydroxylated additives tested in stabilizing dried spotted antibodies and maintaining their bioactivity in sandwich assays. Background fluorescence intensity from additives was assessed using corresponding print buffers lacking antibody as negative controls: buffer, buffer + glycerol (2\%), buffer + PVA (0.5\%), buffer + PVA (0.05\%). Serial dilutions $(20 \mathrm{ng} / \mathrm{ml}, 2 \mathrm{ng} /$ $\mathrm{ml}, 200 \mathrm{pg} / \mathrm{ml}, 20 \mathrm{pg} / \mathrm{ml}$ ) of cytokine analytes (recombinant human IL-1 $\beta, \mathrm{TNF} \alpha$ and IL-4) were probed in sandwich assays and scanned images for $20 \mathrm{ng} / \mathrm{ml}$ and $200 \mathrm{pg} / \mathrm{ml}$ are shown in Figure 4 (complete scanned images were shown in supplemental data). Negative controls containing buffer + glycerol $(2 \%)$ shown in Figure 4's white box exhibit a strong false positive fluorescence signal (Cy5 channel) on amine-reactive OptArray ${ }^{\mathrm{TM}}$ slides. Unlabeled capture antibodies printed with glycerol (2\%) additives showed similar fluorescence intensities in sandwich assays for both $20 \mathrm{ng} / \mathrm{ml}$ and $200 \mathrm{pg} / \mathrm{ml}$ cytokine analyte concentrations, whereas fluorescence intensity signals (Cy5 channel) for assays using antibodies printed with PVA $(0.5 \%$ and $0.05 \%)$ additives, or printed without any additive, correspond to respective analyte concentrations. High fluorescence intensities (Cy5 channel) on OptArray ${ }^{\mathrm{TM}}$ slides are attributed to glycerol autofluorescence after drying on this chemistry, not from printed capture antibodies. Buffer control and antibodies printed with glycerol (2\%) additives on pre-blocked deactivated OptArray $^{\mathrm{TM}}$, amine-reactive Codelink ${ }^{\mathrm{TM}}$, and pre-blocked Codelink ${ }^{\mathrm{TM}}$ slides showed no such false positive signals.

Interestingly, as shown in Figures 4 and 5, deactivating amine-reactive groups on both OptArray $^{\mathrm{TM}}$ and Codelink ${ }^{\mathrm{TM}}$ surface with ethanolamine before microarray printing did not substantially alter fluorescence intensities in $\mathrm{Cy} 3$ and $\mathrm{Cy} 5$ detection channels on pre-blocked slides compared to unblocked amine-reactive slides (Cy3 fluorescence images shown in supplement data). Even stronger analyte fluorescence signal was observed on pre-blocked antibody-printed slides, representing similar or even improved antibody printing/ immobilization and analyte capture activity without surface covalent reaction. Amine-reactive covalent binding is therefore not a distinguishing performance feature in this particular microarray contact printing system. Antibodies are seemingly immobilized onto these commercial array surfaces primarily through drying, by antibody-antibody aggregation and physisorption interactions including hydrogen bonding, electrostatic interactions and van der Waals forces. This result is consistent with that with proteins printed on Codelink ${ }^{\mathrm{TM}}$ slides in a previous study 45 . Antibodies are basically dried down onto substrate surfaces. Many possible forces can be involved in this immobilization process. Small contributions from covalent binding between antibody lysine amine groups and amine-reactive commercial slide chemistries are masked by many physical interactions produced by rapid spot drying. 
In Figure 5, fluorescence intensities (Cy5 channel) were quantified for capture antibodies printed without any print additive versus with PVA (5\%), and plotted against cytokine analyte concentration. On unblocked amine-reactive OptArray ${ }^{\mathrm{TM}}$ and Codelink ${ }^{\mathrm{TM}}$ slides, adding PVA (5\%) to print buffer outperformed print buffer without any additive in capture activity for all three tested capture antibodies. This is consistent with capture activity data in Figure 3. For the identical sample (same antibody printed with same additive), capture antibodies printed on deactivated pre-blocked slides show improved analyte capture activities over those printed on unblocked activated slides. This is more apparent on Codelink ${ }^{\mathrm{TM}}$ slides, with the highest analyte capture signal obtained from antibodies printed without any additive on deactivated preblocked slides. For antibodies printed with the same additive, this improved bioactivity is directly related to increased capture antibody immobilization density witnessed on pre-blocked slides, as exhibited by antibody printed fluorescence intensity (Cy3 fluorescence images shown in supplementary data). Covalent ethanolamine blocking prior to microarray printing not only consumes amine-reactive chemistry on slide substrate surfaces, but also produces hydroxyl groups (i.e., primary amine nucleophilicity is several orders higher than hydroxyl reactivity 56 ). This change in surface chemistry produces new interactions between surfaces and capture antibodies, resulting in increased capture antibody immobilization and binding activity on preblocked slides versus unblocked slides. Furthermore, different surface chemistry also results in different influences on PVA-surface and PVA-protein interactions.

Assay detection limits (defined as 3 times the average fluorescence intensity of corresponding print buffer background) are approximately $200 \mathrm{pg} / \mathrm{ml}$ for IL-4, and near $20 \mathrm{ng} / \mathrm{ml}$ for IL- $1 \beta$ and TNF $\alpha$ (supplemental data). Linear response ranges for the assays are $200 \mathrm{pg} / \mathrm{ml} \sim 20 \mathrm{ng} /$ $\mathrm{ml}$ for IL-4, and $20 \mathrm{pg} / \mathrm{ml} \sim 2 \mathrm{ng} / \mathrm{ml}$ for IL-1 $\beta$ and TNF $\alpha$ (Figure 5). Different capture antibodies and secondary antibodies have widely varying binding efficiencies to respective analytes, producing different response ranges and detection limits in microarray formats. These differences are manifested in differential signals characteristic of each printed antibody, where assay signals do not represent absolute analyte abundance, but a combination of relative abundance, printed, dried antibody density, dried antibody efficiency, and resulting affinity for analyte capture. Additionally, ultimate assay detection limits could be further optimized by surveying all possible analyte-specific antibodies in paired sandwich formats to minimize antibody cross-reactivity and maximize analyte sensitivity.

\section{Printed antibody microarray shelf life}

Storing printed antibody microarray slides is an important and necessary process in practical microarray utilization. The ability to reliably maintain antibody activity on microarray slides under storage is therefore an essential performance element for both microarray manufacturer and user. Pre-printed commercial formats are generally stored dry until shipped and used; wet storage presents numerous practical issues. Printed antibody microarray slides stored in wet conditions (blocking solutions, protein stabilizing additives) could compromise antibody immobilization. Antibodies adsorbed only through physical interaction (shown here to be significant) could desorb and diffuse into storage solutions over time ${ }^{18}$. Dry storage conditions at $4{ }^{\circ} \mathrm{C}$ have been reported by several previous studies 18,19 . Printed antibody microarrays (anti-human IL-1 $\beta$ microarray data shown in Figure 6) were therefore stored at $4^{\circ} \mathrm{C}$, and sealed under nitrogen for 1 month. After this period, slides were brought to room temperature and assayed. Quantified fluorescence signal (Cy5 channel data) was compared to microarray slides printed at the same time, but assayed after only overnight storage under the same conditions. Figure 6 shows that capture activities for antibodies printed both with all hydroxylated additives and without any additives all decreased after 1-month storage. With PVA additives, capture activity after storage remains at reasonable levels, higher than capture activities of antibodies printed with most other additives or without any additive at day 1. 


\section{Conclusions}

Analyte capture capabilities for printed, desiccated anti-human IL-1 $\beta$, IL-4 and TNF $\alpha$ antibody microarrays on two commercial amine-reactive polymer slides were improved by addition of PVA (mol. wt. 9000, $0.05 \sim 0.5 \%$ ) to the print buffer. PVA demonstrated the best performance among several hydroxylated additives in terms of spotted antibody distribution homogeneity, uniform microspot morphology, immobilized antibody bioactivity, and spot-to-spot variance. PVA also maintained antibody capture activity reasonably well after 1-month storage under dry conditions at $4^{\circ} \mathrm{C}$. Ideally, the capture antibody should form a bound, bioactive monolayer in each microarray spot, with retention of full analyte selectivity, capture bioactivity and lack of cross-reactivity. However, the influence of multiple factors including varying surface chemistry, printing conditions, different antibody sources and analyte affinities, assay conditions and printing durability, makes realization of universal optimized printing and assay parameters applicable to all capture antibodies on all arraying surfaces likely impossible.

Antibody microarray assays have significant reliability and metric challenges. Considerable variations in antibody properties, including variable batch-batch, non-standardized sourcing and intrinsic on-array stability variability, printing behaviors including surface loading, intraspot antibody distribution in microarray spots, spot homogeneity, immobilized antibody density reproducibility, reliable fiduciary markers or on-array calibrating standards, print-print and slide-slide variance, and antibody desiccation survival post-printing all require attention for improved array performance. Without improved antibody printing/immobilization strategies on surfaces, hydroxylated print additives contribute only marginally to improve analyte capture activities of printed antibodies. Physisorption, not covalent immobilization, dominates antibody-surface printing interactions on two commercial polymer arraying slides, forced by rapid array spot desiccation. Under these common print conditions and storage, antibody covalent attachment is not a reliable parameter in contact microarray print stability and array performance.

\section{Supplementary Material}

Refer to Web version on PubMed Central for supplementary material.

\section{Acknowledgements}

The authors acknowledge support from NIH grant EB00726. Gift of OptArray ${ }^{\mathrm{TM}}$ slides from Accelr8 (Denver, CO), and technical guidance and reproducible spotting protocols from Dr. C. Greef (Accelr8) are gratefully acknowledged.

\section{References}

1. Haab BB. Proteomics 2003;3:2116-2122. [PubMed: 14595810]

2. Templin MF, Stoll D, Schwenk JM, Potz O, Kramer S, Joos TO. Proteomics 2003;3:2155-2166. [PubMed: 14595815]

3. Glokler J, Angenendt P. J Chromatogr B Analyt Technol Biomed Life Sci 2003;797:229-240.

4. Li Y, Nath N, Reichert WM. Anal Chem 2003;75:5274-5281.

5. McQuain Mark K, Seale K, Peek J, Levy S, Haselton Frederick R. Anal Biochem 2003;320:281-291. [PubMed: 12927835]

6. Kusnezow W, Hoheisel Jorg D. BioTechniques 2002;(Suppl):14-23. [PubMed: 12514925]

7. Reichert WM, Blawas AS. Biomaterials 1998;19:595-609. [PubMed: 9663732]

8. Zhu H, Snyder M. Curr Opin Chem Biol 2001;5:40-45. [PubMed: 11166646]

9. Adamson, A. Physical Chemistry of Surfaces. 5. Wiley; New York: 1990.

10. Rey, L.; May, JC. Freeze-Drying/Lyophilization of Pharmaceutical and Biological Products. MarcelDekkar; NY: 1999. 
11. Brash, JL.; Horbett, TA. ACS Symp Ser vol 602. ACS Press; Washington, D.C: 1995.

12. Haynes CA, Norde W. Coll Surf B 1994;2:517-566.

13. Kingshott P, Griesser HJ. Curr Opin Solid State Mater Sci 1999;4:403-412.

14. Malmsten, M. Biopolymers at Interfaces. 2. Marcel-Dekkar; NY: 2003.

15. Norde W. Adv Colloid Interface Sci 1986;25:267-340. [PubMed: 3333131]

16. Gong P, Harbers GM, Grainger DW. Anal Chem 2006;78:2342-2351. [PubMed: 16579618]

17. Mendoza LG, McQuary P, Mongan A, Gangadharan R, Brignac S, Eggers M. BioTechniques 1999;27:778-788. [PubMed: 10524321]

18. Angenendt P, Glokler J, Murphy D, Lehrach H, Cahill Dolores J. Anal Biochem 2002;309:253-260. [PubMed: 12413459]

19. Kusnezow W, Jacob A, Walijew A, Diehl F, Hoheisel JD. Proteomics 2003;3:254-264. [PubMed: 12627378]

20. Lee CS, Kim BG. Biotechnol Lett 2002;24:839-844.

21. Pikal, MJ. Drugs and the Pharmaceutical Sciences. Rey, L.; May, JC., editors. 96. Marcel Dekker; NY: 1999. p. 161-198.

22. Crowe JH, Carpenter JF, Crowe LM. Annu Rev Physiol 1998;60:73-103. [PubMed: 9558455]

23. Pereira CS, Lins RD, Chandrasekhar I, Freitas LCG, Huenenberger PH. Biophys J 2004;86:22732285. [PubMed: 15041666]

24. Crowe JH, Crowe LM, Carpenter JF. BioPharm (Duluth, MN, United States) 1993;6:28-29. 32-23.

25. Crowe JH, Crowe LM, Carpenter JF. BioPharm (Duluth, MN, United States) 1993;6:40-43.

26. Remmele RL Jr, Stushnoff C, Carpenter JF. Pharm Res 1997;14:1548-1555. [PubMed: 9434273]

27. Arakawa T, Timasheff SN. Biophys J 1985;47:411-414. [PubMed: 3978211]

28. Timasheff SN. Annu Rev Biophys Biomol Struct 1993;22:67-97. [PubMed: 8347999]

29. Clegg JS. Comp Biochem Physiol B Biochem Mol Biol 2001;128:613-624. [PubMed: 11290443]

30. Crowe LM. Comp Biochem Physiol A Mol Integr Physiol 2002;131:505-513. [PubMed: 11867276]

31. Sun WQ, Leopold AC. Comp Biochem Physiol A Mol Integr Physiol 1997;117A:327-333.

32. MacBeath, G.; Schreiber, SL. Science. 289. Washington, D. C: 2000. p. 1760-1763.

33. Levit-Binnun N, Lindner AB, Zik O, Eshhar Z, Moses E. Anal Chem 2003;75:1436-1441. [PubMed: 12659207]

34. Girke T, Todd J, Ruuska S, White J, Benning C, Ohlrogge J. Plant Physiol 2000;124:1570-1581. [PubMed: 11115875]

35. Huang RP, Yang W, Yang D, Flowers L, Horowitz IR, Cao X, Huang R. Expert Opin Ther Targets 2005;9:601-615. [PubMed: 15948677]

36. Satwani P, Morris E, van de Ven C, Cairo MS. Biol Neonate 2005;88:214-227. [PubMed: 16210844]

37. Blawas AS, Reichert WM. Biomaterials 1998;19:595-609. [PubMed: 9663732]

38. Deegan RD, Bakajin O, Dupont TF, Huber G, Nagel SR, Witten TA. Nature (London) 1997;389:827829.

39. Pirrung MC. Angew Chem, Int Ed 2002;41:1276-1289.

40. Gong P, Grainger DW. Biomed Sci Instrum 2004;40:18-23. [PubMed: 15133929]

41. Kaushik JK, Bhat R. J Biol Chem 2003;278:26458-26465. [PubMed: 12702728]

42. Chang LL, Shepherd D, Sun J, Ouellette D, Grant KL, Tang XC, Pikal MJ. J Pharm Sci 2005;94:1427_ 1444. [PubMed: 15920775]

43. Sola-Penna M, Meyer-Fernandes JR. Arch Biochem Biophys 1998;360:10-14. [PubMed: 9826423]

44. Nichkova M, Dosev D, Perron R, Gee SJ, Hammock BD, Kennedy IM. Anal Bioanal Chem 2006;384:631-637. [PubMed: 16416096]

45. Wu P, Hogrebe P, Grainger DW. Biosens Bioelectron 2006;21:1252-1263. [PubMed: 16002276]

46. Boyd S, Yamazaki H. Immunol Invest 1995;24:795-803. [PubMed: 8543343]

47. Liao YH, Brown MB, Jones SA, Nazir T, Martin GP. Int J Pharm 2005;304:29-39. [PubMed: 16181753]

48. Sakai Y, Yasueda S, Ohtori A. Int J Pharm 2005;305:176-179. [PubMed: 16207517] 
49. Hill JJ, Shalaev EY, Zografi G. J Pharm Sci 2005;94:1636-1667. [PubMed: 15965985]

50. Heller MC, Carpenter JF, Randolph TW. Biotechnol Prog 1997;13:590-596. [PubMed: 9336978]

51. Liao YH, Brown MB, Quader A, Martin GP. Pharm Res 2002;19:1854-1861. [PubMed: 12523665]

52. Griebenow K, Klibanov AM. Proc Natl Acad Sci U S A 1995;92:10969-10976. [PubMed: 7479920]

53. Kachalova GS, Morozov VN, Morozova T, Myachin ET, Vagin AA, Strokopytov BV, Nekrasov Yu V. FEBS Lett 1991;284:91-94. [PubMed: 2060633]

54. Rupley JA, Careri G. Adv Protein Chem 1991;41:37-172. [PubMed: 2069077]

55. Cicerone MT, Soles CL, Chowdhuri Z, Pikal MJ, Chang L. Am Pharm Rev 2005;8:22-24. 27.

56. Hermanson, GT. Bioconjugate Techniques. Academic Press; San Diego, California: 1995. 


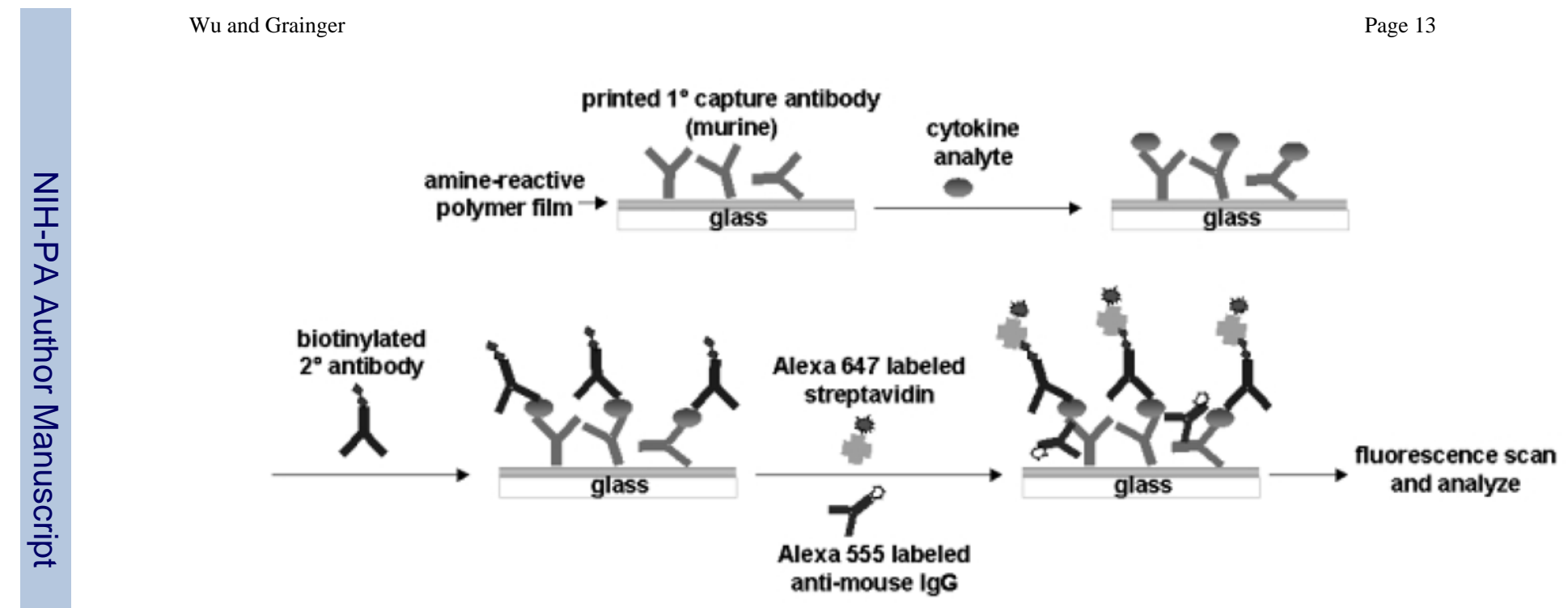

Figure 1.

Anti-human cytokine sandwich immunoassay scheme 
(a) OptArray ${ }^{\mathrm{TM}}$ slide

Intra spot variation

$\begin{array}{ll}\text { anti-IL-1 } \beta & 165.5 \% \pm 4.7 \% \\ \text { anti-IL-1 } \beta+\text { trehalose (0.5\%) } & 168.1 \% \pm 12.8 \% \\ \text { anti-lL-1 } \beta+\text { glycerol (2\%) } & 151.0 \% \pm 5.8 \% \\ \text { anti-lL-1 } \beta+\text { PEG (150, 5\%) } & 111.0 \% \pm 33.8 \% \\ \text { anti-IL-1 } \beta+\text { PEG (2000, 0.5\%) } & 183.0 \% \pm 18.4 \% \\ \text { anti-IL-1 } \beta+\text { PEG (2000, 5\%) } & 239.4 \% \pm 29.6 \% \\ \text { anti-IL-1 } \beta+\text { PVA (9000,0.05\%) } & 38.6 \% \pm 5.2 \% \\ \text { anti-IL-1 } \beta+\text { PVA (9000,0.5\%) } & 38.6 \% \pm 2.7 \%\end{array}$

\section{(b) Codelink ${ }^{\mathrm{TM}}$ slide}

\section{Intra spot variation}

anti-LL-1 $\beta \quad 65.3 \% \pm 2.2 \%$

anti-lL-1 $\beta+$ trehalose $(0.5 \%) \quad 61.6 \% \pm 2.4 \%$

anti-lL-1 $\beta+$ glycerol $(2 \%) \quad 64.0 \% \pm 6.0 \%$

anti-lL-1 $\beta+$ PEG (150, $5 \%) \quad 148.7 \% \pm 8.4 \%$

anti-lL-1 $\beta+$ PEG $(2000,0.5 \%) \quad 140.0 \% \pm 2.2 \%$

anti-lL-1 $\beta+$ PEG $(2000,5 \%) \quad 163.4 \% \pm 19.7 \%$

anti-IL-1 $\beta+$ PVA $(9000,0.05 \%) \quad 22.9 \% \pm 2.3 \%$

anti-lL-1 $\beta+$ PVA $(9000,0.5 \%) \quad 43.5 \% \pm 2.5 \%$

\section{DIC Fluorescence}

anti-IL-1 $\beta$ : no additives
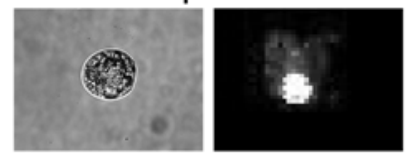

anti-IL-1 $1 \beta+$ trehalose $(0.5 \%)$

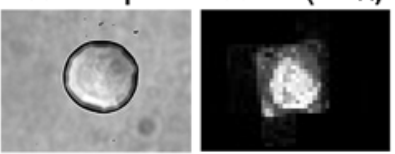

anti-IL-1 $\beta+$ glycerol (2\%)
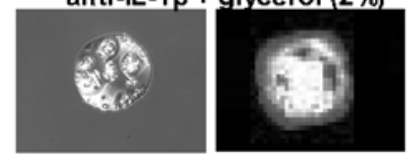

anti-IL-1 + PEG $150(5 \%)$
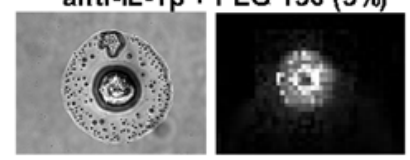

DIC Fluorescence

anti-IL-1 $\beta$ : no additives
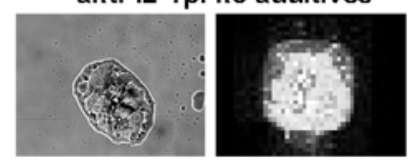

anti-IL-1 $\beta+$ trehalose $(0.5 \%$
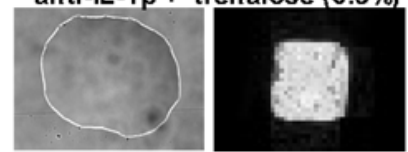

anti-IL-1 $\beta+$ glycerol ( $2 \%)$
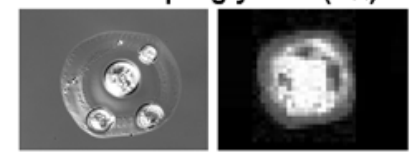

anti-IL-1 $\beta$ + PEG 150 (5\%)

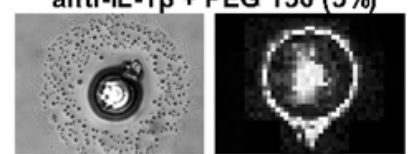

DIC Fluorescence

anti-IL-1 $\beta$ + PEG $2000(0.5 \%)$

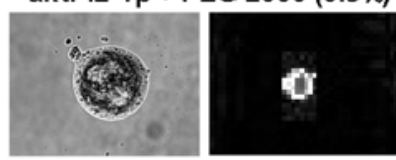

anti-IL-1 1 + PEG 2000 (5\%)

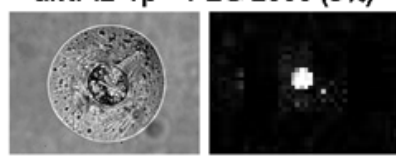

anti-IL-1 $1 \beta$ PVA $9000(0.05 \%)$

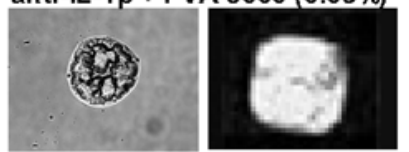

anti-IL-1 $\beta$ + PVA $9000(0.5 \%)$

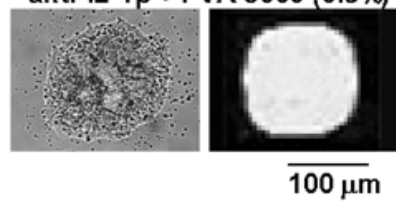

DIC Fluorescence

anti-IL-1 $\beta$ + PEG 2000 (0.5\%)

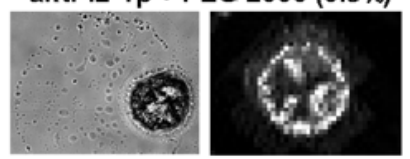

anti-IL-1 $1 \beta$ + PEG $2000(5 \%)$

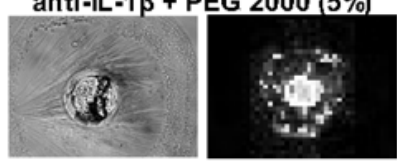

anti-IL-1 $\beta$ + PVA $9000(0.05 \%)$

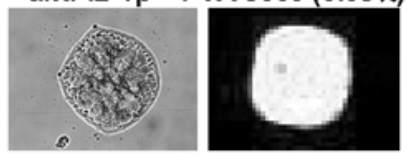

anti-IL-1 + PVA $9000(0.5 \%)$
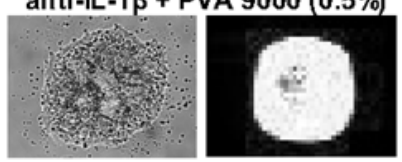

$\overline{100 \mu \mathrm{m}}$

Figure 2.

Digital microscope images of printed microarray spots (before blocking, rinse and protein analyte assay) under differential interference contrast (DIC) microscopy, and fluorescence scanned images of printed microarray spots after rinse and sandwich assays. For each sample, two images were taken (left: DIC image; right: fluorescence image). Images for the same sample were not taken on the same spot, but these images were representative of antibody samples printed with different additives. Intra-spot fluorescence intensity variations were calculated using ScanArray Express ${ }^{\mathrm{TM}}$ software $(\mathrm{n}=5)$. 
(a)

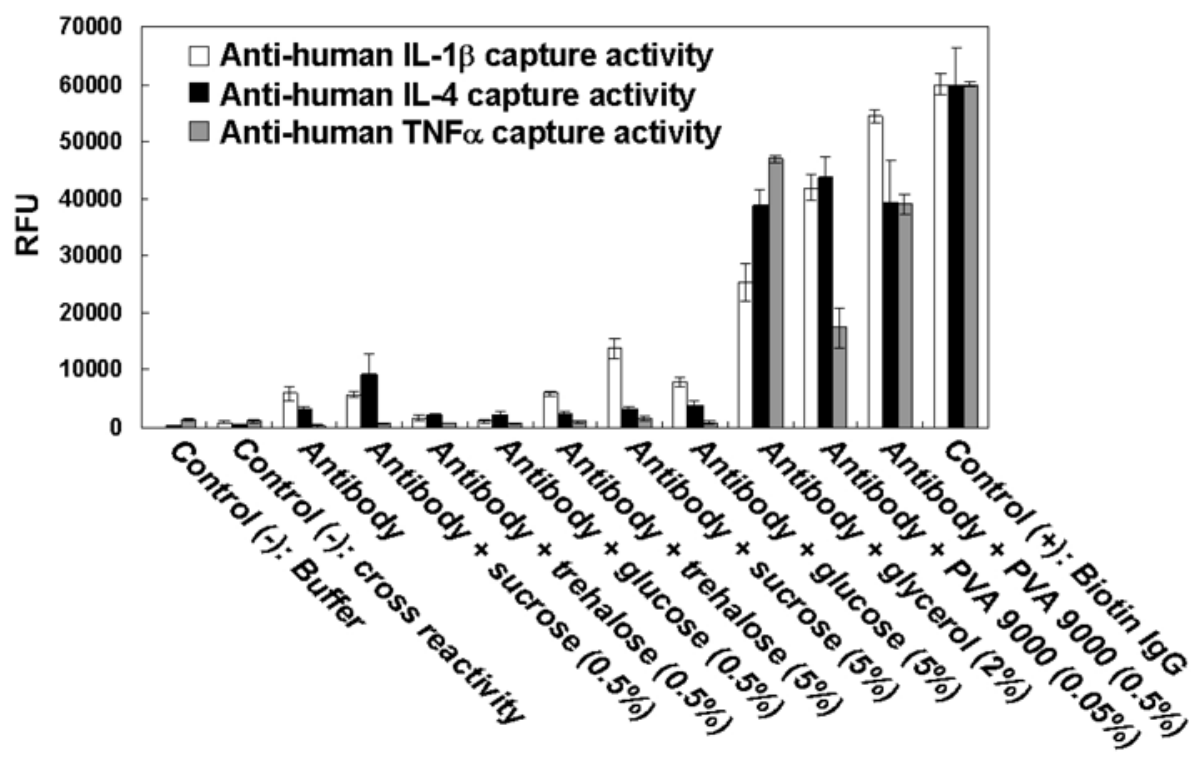

(b)

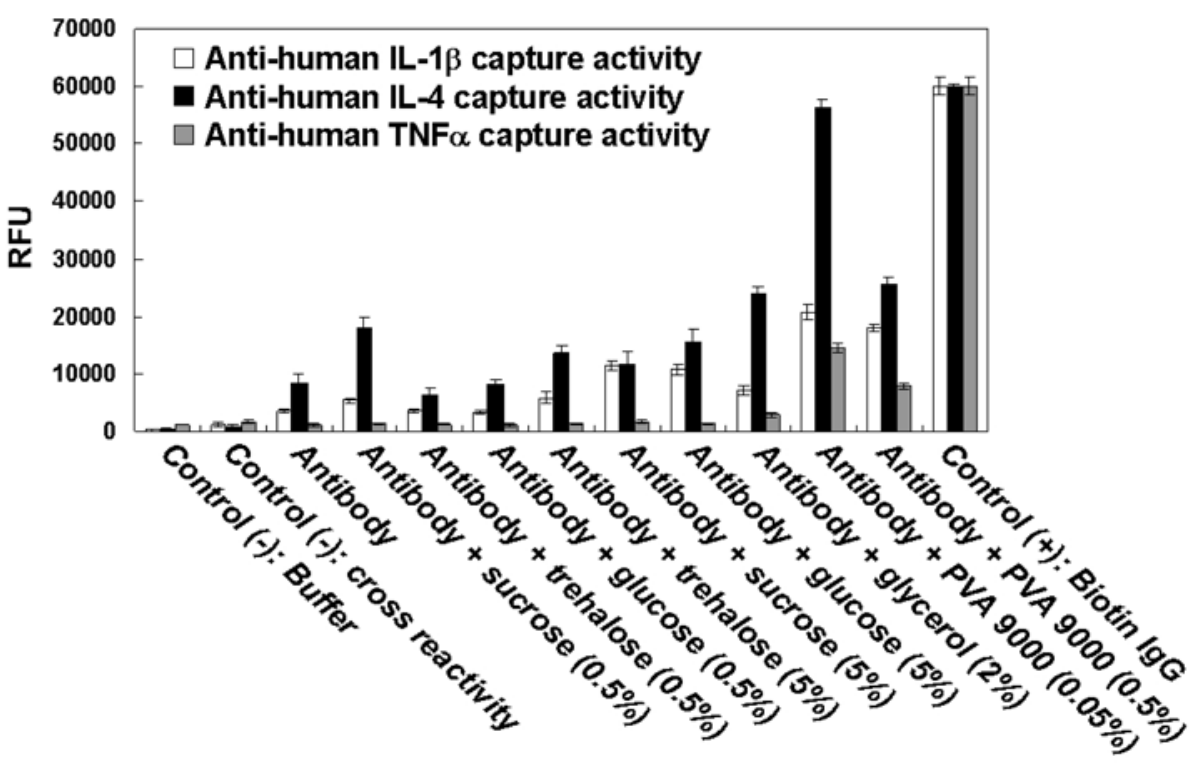

Figure 3.

Quantified streptavidin-Alexa Fluor ${ }^{\circledR} 647$ fluorescence intensity (Cy5 scanner channel) representing activity of printed anti-human cytokine antibodies in sandwich assay. Anti-human IL-1 $\beta(100 \mu \mathrm{g} / \mathrm{ml}$ printed concentration), anti-human IL-4 (200 $\mu \mathrm{g} / \mathrm{ml}$ printed conc.) and antihuman TNF $\alpha(200 \mu \mathrm{g} / \mathrm{ml}$ printed conc.) were printed into three individual microarrays on (a) OptArray ${ }^{\mathrm{TM}}$ and (b) Codelink ${ }^{\mathrm{TM}}$ polymer microarray surfaces with different print buffer additives. Relative fluorescence intensities (RFU) of positive control (printed biotinylated nonspecific $\mathrm{IgG})$ in each microarray were normalized to the same $R F U$ value $(60,000)$. RFU signals of anti-human cytokine samples were then normalized to positive controls, marked (+), in each microarray. Two negative controls, marked (-) were used in these experiments: (1) pure buffer, and (2) cross reactivity controls: anti-human IL- $1 \beta$ secondary antibody applied to anti-human 
IL-4 and anti-human TNF $\alpha$ primary microarrays; and anti-human TNF $\alpha$ secondary antibody applied to anti-human IL-1 $\beta$ primary microarrays $(n=5$ spots $) .(+)=$ positive control; $(-)=$ negative control. 
(a) IL-1 $\beta$, IL-4 and TNF $\alpha$ (analyte conc. 20ng/mI)
OptArrayTM

CodelinkTM

(b) IL-1 $\beta$, IL-4 and TNF $\alpha$

(analyte conc. 200 pg/ml)

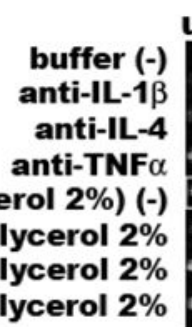

buffer + PVA 9000 (0.05\%)(-) anti-IL-1 $\beta$ + PVA $9000(0.05 \%)$

anti-IL-4 + PVA $9000(0.05 \%)$

anti-TNF $\alpha+$ PVA $9000(0.05 \%)$

buffer + PVA 9000 (0.5\%) (-)

anti-IL-1b + PVA 9000 (0.5\%)

anti-IL-4 + PVA 9000 (0.5\%)

anti-TNFa + PVA $9000(0.5 \%)$

BlgG (50 $\mu \mathrm{g} / \mathrm{ml})(+)$ unblocked pre-blocked
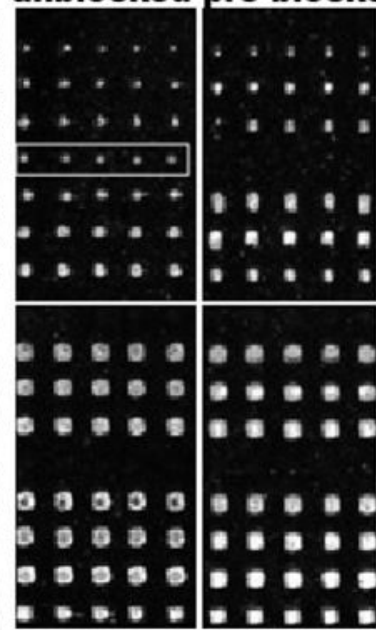

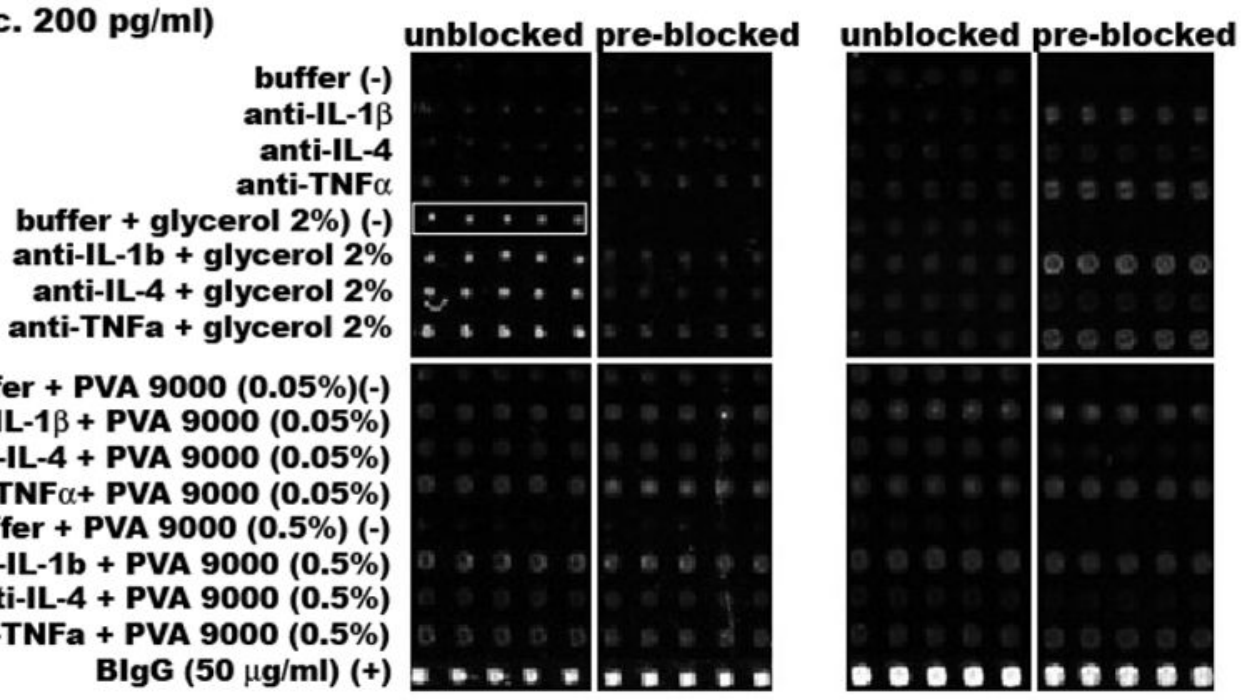

Figure 4.

Array fluorescence scanned images (Cy5 scanner channel) showing analyte capture activity for anti-human IL-1 $\beta(100 \mu \mathrm{g} / \mathrm{ml}$ printed concentration), anti-human IL-4 (200 $\mu \mathrm{g} / \mathrm{ml}$ printed conc.) and anti-human TNF $\alpha(200 \mu \mathrm{g} / \mathrm{ml}$ printed conc.) printed with glycerol, PVA, and without any additives on both amine-reactive OptArray ${ }^{\mathrm{TM}}$ and Codelink ${ }^{\mathrm{TM}}$ array slides (both unblocked and pre-blocked with ethanolamine) in cytokine analyte sandwich assays. Serial cytokine analyte concentrations $20 \mathrm{ng} / \mathrm{ml}, 2 \mathrm{ng} / \mathrm{ml}, 200 \mathrm{pg} / \mathrm{ml}$ and $20 \mathrm{pg} / \mathrm{ml}$ concentrations (descending order) were used in sandwich assays. For clarity, fluorescence scanned images of only (a) $20 \mathrm{ng} / \mathrm{ml}$ and (b) $200 \mathrm{pg} / \mathrm{ml}$ are shown. $(+)=$ positive control; $(-)=$ negative control. unblocked pre-blocked

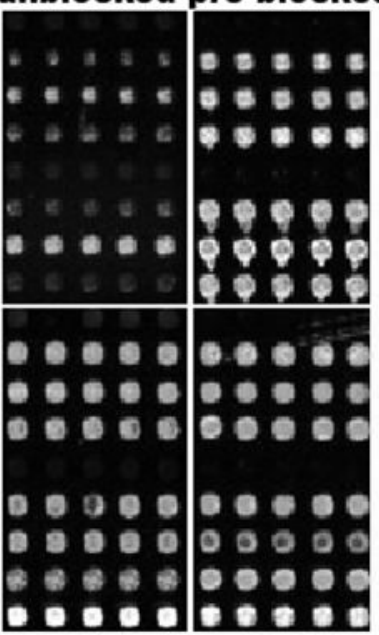




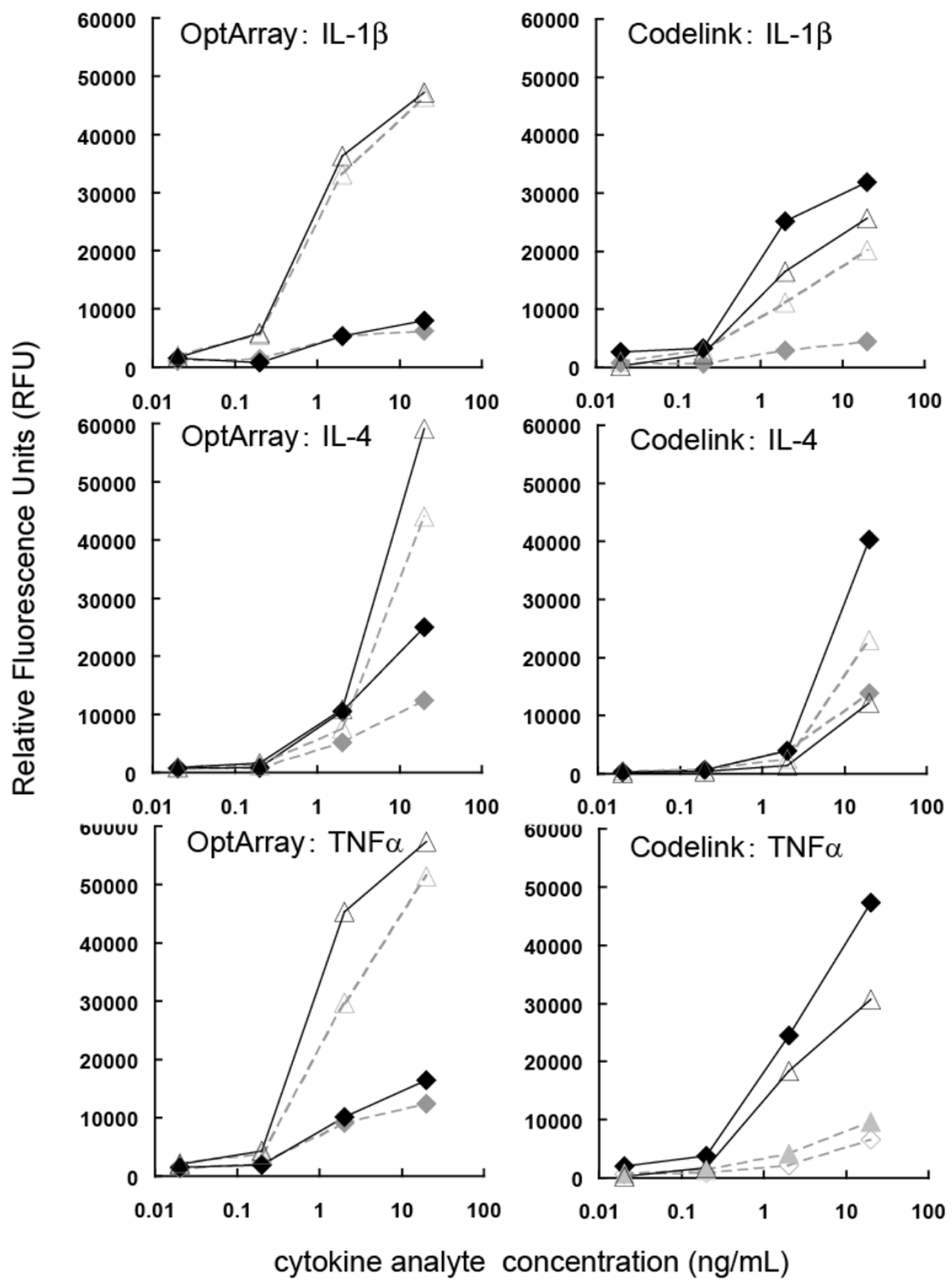

Figure 5.

Quantified streptavidin-Alexa Fluor® 647 fluorescence intensities (Cy5 scanner channel) for cytokine analyte capture in antibody sandwich assays shown in Figure 4, showing activity of anti-human cytokines printed without any additive, or with PVA (M.W. 9000, 0.5\%) on both OptArray ${ }^{\mathrm{TM}}$ and Codelink ${ }^{\mathrm{TM}}$ array slides as a function of cytokine analyteconcentration. $(\Delta$ : antibody + PVA $(0.5 \%)$ on pre-blocked slides; $\triangle$ : antibody + PVA (0.5) on amine-reactive slides; : antibody on pre-blocked slides; $\diamond$ : antibody on amine-reactive slides. $\mathrm{n}=5$ spots; error bars/standard variation smaller than graph symbols. 

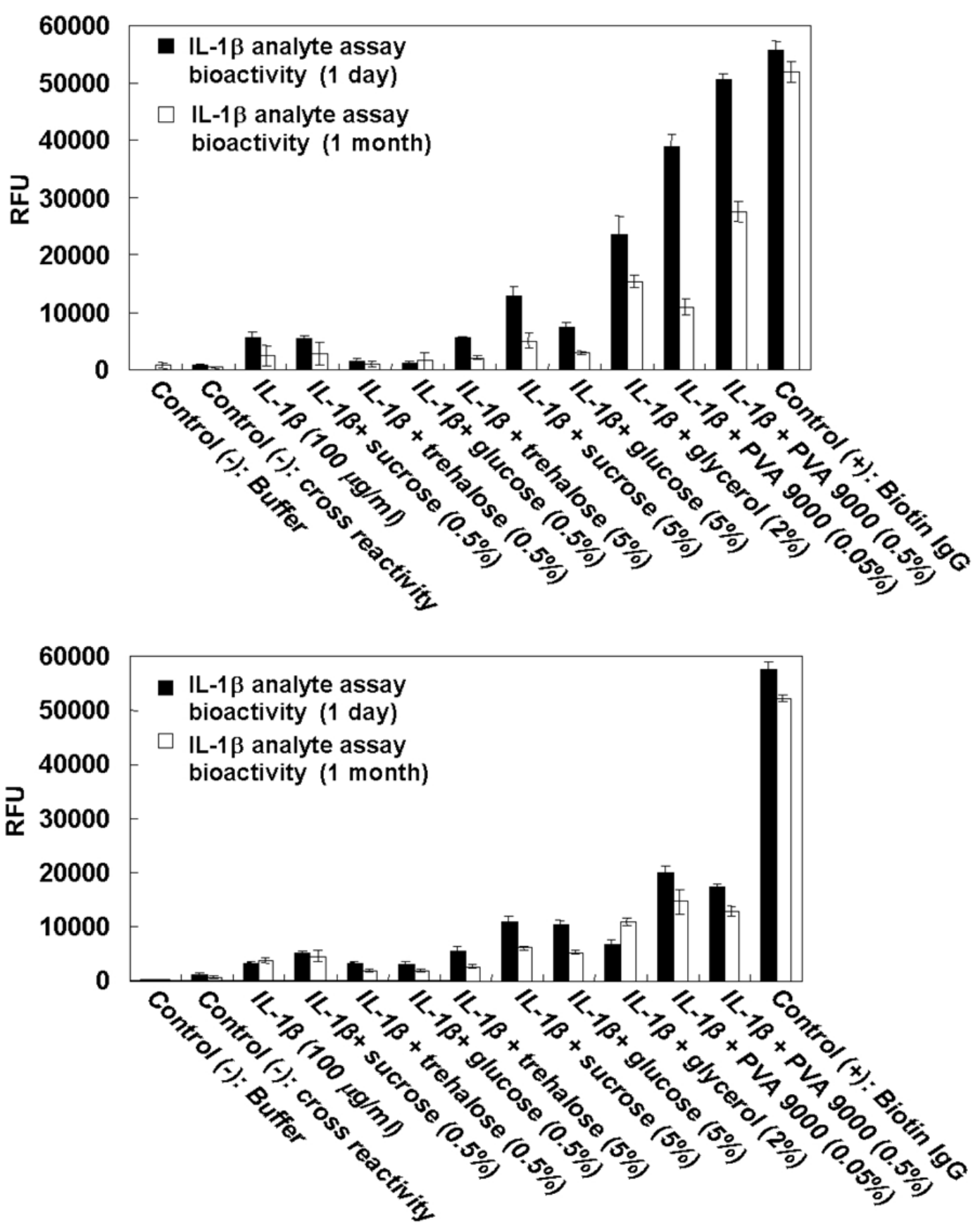

Figure 6.

Quantified streptavidin-Alexa Fluor ${ }^{\circledR} 647$ fluorescence intensity showing activity of printed anti-human IL-1 $\beta$ on (a) OptArray ${ }^{\mathrm{TM}}$ and (b) Codelink ${ }^{\mathrm{TM}}$ array slides after 1 day and 1 month storage dry under nitrogen at $4{ }^{\circ} \mathrm{C}$, with different print buffer additives (labeled as IL-1 $\beta+$ different additives $)$ in cytokine sandwich assays $(n=5$ spots $) .(+)=$ positive control; $(-)=$ negative control. 
Table 1

Vendors and sources of assay capture antibodies

Supplier

Anti-human IL-4( $1^{\circ}$ capture $)$ Anti-human IL-4 ( $2^{\circ}$ biotinylated $)$ Anti-human IL-1 $\beta$ ( $1^{\circ}$ capture $)$

Anti-human IL-1 $\beta$ ( $2^{\circ}$ biotinylated $)$

Anti-human $\mathrm{TNF} \alpha\left(1^{\circ}\right.$ capture $)$

Anti-human $\mathrm{TNF} \alpha\left(2^{\circ}\right.$ biotinylated $)$
R\&D Systems (Minneapolis, MN)

R\&D Systems (Minneapolis, MN)

R\&D Systems (Minneapolis, MN) Pierce (Rockford, IL)

R\&D Systems (Minneapolis, MN) Pierce (Rockford, IL)

R\&D Systems (Minneapolis, MN) Pierce (Rockford, IL)

R\&D Systems (Minneapolis, MN) Pierce (Rockford, IL)
Source

Monoclonal, Mouse Polyclonal, Goat Monoclonal, Mouse Monoclonal, Mouse Polyclonal, Goat Monoclonal, Mouse Monoclonal, Mouse Monoclonal, Mouse Polyclonal, Goat Monoclonal, Mouse 